\title{
THE URBAN ISSUE IN BRAZIL: A LOOK AT THE URBAN VIOLENCE IN NATIONAL CITIES
}

\author{
M. J. O. ALEXANDRE and G. G. NASCIMENTO* \\ Instituto Federal de Educação, Ciência e Tecnologia do Rio Grande do Norte - Campus Natal-Central \\ gerson.nascimento@ifrn.edu.br
}

Article received December/2014 and accepted in December/2014

DOI: 10.15628/geoconexoes.2015.2647

\section{ABSTRACT}

The urban space, especially in the metropolitan urban area peripheral countries such as Brazil has undergone many transformations over time. These changes are felt mainly in its space sociopolitical structure, which in turn shows the spatiality of our metropolises, with an emphasis on Rio de Janeiro and São Paulo for being the two largest Brazilian metroplises, however, and concentrators are witnesses of worsening urban problem that is increasing every day in the country. In this sense, we have to consider some aspects, throughout the history of the country, and contributed to, somehow, today, still contribute to the worsening of problems related to the increase in urban violence, especially in
\end{abstract}

outlying areas such as slums, the poorest areas in these cities. We conclude that a fair and guarantor of a good quality of life depends urban space of a just society, but the reverse is also true. Overcome the problems associated with urban question emerges not only eliminate social relations that generated, but also overcome the spatiality that induces the reproduction of these relations at all scales, mainly local. These transformations require, in fact, a confrontation of the capitalist civilization model itself without which we cannot aspire to a more equitable social development in these large cities.

KEYWORDS: Brazil. Urban Violence. National Metropolis.

\section{A QUESTÃO URBANA NO BRASIL: UM OLHAR SOBRE A VIOLÊNCIA URBANA NAS METRÓPOLES NACIONAIS}

\section{RESUMO}

O espaço urbano, sobretudo o espaço urbano metropolitano em países periféricos como o Brasil tem passado por muitas transformações ao longo do tempo. Essas transformações se fazem sentir principalmente no seu tecido sociopolítico espacial, que por sua vez se mostra na espacialidade das nossas metrópoles, com destaque especial para o Rio de janeiro e São Paulo por serem as duas maiores metrópoles brasileiro, logo, são concentradoras e testemunhas do agravamento da questão urbana que vem aumentando a cada dia no país. Nesse sentido, há que se considerarem alguns aspectos que, ao longo da história do país, contribuíram e que, de certa forma, nos dias atuais, ainda contribuem para o agravamento de problemas relacionados ao aumento da violência urbana, notadamente nas áreas periféricas como as favelas, áreas mais carentes nessas cidades. Concluímos que, um espaço urbano justo e garantidor de uma boa qualidade de vida dependem de uma sociedade justa, mas o inverso também é verdadeiro. Superar os problemas associados à questão urbana depreende não somente eliminar as relações sociais que a geraram, mas igualmente ultrapassar a espacialidade que induz à reprodução dessas relações em todas as escalas, principalmente a local. Essas transformações requerem, em verdade, um afrontamento do próprio modelo civilizatório capitalista sem o qual não poderemos almejar um desenvolvimento social mais igualitário nessas grandes cidades.

PALAVRAS-CHAVE: Brasil. Violência Urbana. Metrópoles Nacionais. 


\section{INTRODUCTION}

The urban space, especially the metropolitan urban space in peripheral countries like Brazil has gone through many transformations over time. These changes are felt mainly in their spatial socio-political structure, which in turn is shown by the spatiality of our metropolises with particular emphasis to Rio de Janeiro and São Paulo by being the two largest Brazilian metropolises, therefore, are concentrators and witnesses of urban issue worsening which is increasing every day in the country. In this sense, some aspects shall be considered which, throughout the country history contributed, somehow, nowadays, and still contribute to the problems worsening related to the increase of urban violence, especially in remote areas such as slums, the poorest areas in these cities.

The meaning and meaningful of these changes for society, as well as the State and the Brazilian elites responses to such events are in the core of discussions that permeate this study. In this sense, we assume that the urban worsening issue is mainly related to two particular moments, which are related and are equally important to the country history; the first refers to the manner in which Brazil implemented its development process, especially from the 50s; the second is related to a larger context which involves the existing structural obstacles within the capitalist production mode and how it fits into the social issue within each country, through the policies adopted by their governments.

However, we must clarify that in a country with continental dimensions as Brazil and that shows a very heterogeneous reality, the challenge of analyzing and performing relations between urban issue, here understood not only as urban problems, but within a context that has repercussions extremely serious, as it focuses directly on the spatial socio-political structure, involving the dysfunctional increasing of the metropolises dimensions, and constitutes a major challenge to all those who like and discuss this issue. The analytical challenges are huge, and the practical challenges to be driven towards overcoming this situation developed in the metropolises in recent years are even higher.

Overcoming these problems related to urban issues in Brazil will require certainly a set of measures and many efforts from those who are part of the Brazilian civil society, measures ranging from local to national level without, however, forgetting the powerful constraints imposed from outside to inside, which the country has been submitted throughout its history. Valorize and ensure the metropolises survival, using them as a geographical space of social classes' reproduction, trying then to improve the social injustice framework which current dominates them, perhaps is the ultimate action we can do to our metropolises in terms of practical implementation, in the current situation.

1.1 Understanding the urbanization process historicity in Brazil: some important considerations

For a long time, Brazil was recognized as an eminently agrarian and/or better to say, essentially agricultural country. However, the Recôncavo Bahiano and the Northeast Zona da Mata regions already had evidence a significant urbanization process before the other States. According to Santos (1996), Salvador, a city near Cachoeira, Santo Amaro and Nazaré cities, by that time 
considered well significant trade cultural centers and located near the estuary of Recôncavo rivers, had led the first urban networking of the Americas. Referring to the beginnings of urbanization in the country, Reis (1968) shows three main phases of urban territorial organization in the country, from 1500 to 1720 .

Thus, the author emphasizes the first phase of this process from 1500 to 1570 . Notably, from 1530 to 1540 it is highlighted the Rio de Janeiro city foundation in 1567 and Filipéia da Paraíba in 1585. The second period is between 1480 and 1640 according to the author, and refers to Spanish domination years in Brazil emphasizing two greater intensity points, i.e. the years 1610 and 1620 with the records of one village and three cities foundation, and between 1630 and 1640 with the records of nine villages foundation, and consequently, the existence of a systematic urbanization on the north coast and towards the Amazon.

In this sense, still according to the author, the third moment of this process is between 1650 and 1720, period with the records of thirty-five villages' foundation in which two of them were raised to cities: Olinda and São Paulo. In this context, at the end of this period, regarding to urban networking in Brazil, we have a respectable set of sixty-three villages and eight cities. However, in general, is from the eighteenth century that a more developed urbanization is verified since "the city house becomes the most important farmer or the mill owners residence, who only goes to his rural proprieties at cutting and milling cane periods" (Santos apud R. Bastide, p. 19, 1996).

In the late nineteenth century, however, is known the first major acceleration of the urbanization process. According to Santos (1996), 10\% of the country total population was already urban in 1872, keeping this index up to the 1900 years. However, it is highlighted that, if the country urbanization index has changed little between the ends of the colonial period to the ends of the nineteenth century, in only twenty years, this rate has nearly tripled from 1920 to 1940, since the population who lived in cities raised from 4,552,000 people in 1920 to 6,208,699 in 1940. It is highlighted also that, in the same period, the population employed in the service sector had a fastest growth percentage than the total economically active population (Vilela \& Suzigan, p. 71, 1973).

In this context, we may be stated in Santos words that "Brazil was a large archipelago for many centuries, consisting of subspaces developed with its own logic, based largely by its relations with the outside world (Santos, p.26, 1996)". It is from the Second World War, precisely in the middle of the nineteenth century, that the coffee production in Vale do Paraíba, especially in São Paulo State, signs with an urbanization process that begins to show new features. From that time, this State started commanding a dynamic pole of large area covering the most of southern States, still including incompletely Minas Gerais and Rio de Janeiro States.

In this process, it must be also considered an urban infrastructure improvement in the Southeast region as well as the installation, under the international trade inflows, capitalist production, work, exchange, consumption. These characteristics will make possible the economic and urban fluidity of Brazil especially the Southeast region highlighting the São Paulo State. Thus, based on this new dynamic, the industrialization process and consequent urbanization in the country will develop and, as mentioned before, have São Paulo State as your dynamic pole. Thus, it was created a polarization framework "genesis" beginning from Sao Paulo to the other regions of the country until the present days, although each period is according to its own logic. 
From 1940 to 1950, a new dynamic will predominate in the country, grounded in an industrialization process not only with industrial activities in predetermined locations, but with a broader meaning of this term, i.e. like a intense and complex social process, including both the regional market formation and country own integration through the consumption expansion in varying ways, pushing the life of relations, enabling its own urbanization process in the country. This new economic basis will exceed the regional level, in a national scale, pushing increasingly the demographic growth of medium and large cities, especially state capitals.

The development model adopted in Brazil from the 1950s and the consequent formation of an integrated national market led to a chained metropolization processes and, recently, to an urban and demographic interiorization. Initially, there was an accelerated metropolization, based on the growth of some large capitals, but then it lose impulse in front of small and medium cities multiplication and a new metropolization, now, spread by numerous smaller urban spaces. However, this metropolization process, especially in major urban centers of the country and its consequent economic development over social detriment, produced many serious socio-spatial problems regarding to urban issue.

The industrial expansion from that period in Brazil accelerated the growth of some cities, as already mentioned, to which were focused the largest investments and more modern activities, turning them into important centers of development and population attraction. Thus, urban agglomerations were formed with more than one million inhabitants denominated millionaire cities by Santos.

The economy internationalization produced urban agglomerations which became, at the same time, attracting poles of large investments and poverty multiplication centers and with serious socio-spatial problems. The population of these cities grew more rapidly than job, housing, urban infrastructure and social services offerings, which contributed to the worsened of poor people living conditions and an urban violence scenario was constituted, particularly in slums where health conditions are poor and the land is subject to landslides and floods.

The 'metropolitan areas' were created by federal law in the mid-1970s in order to facilitate planning in densely populated areas of the country, i.e. government planning regions which are characterized by a junction of several cities in a large urban area, characterized by diverse activities integration, high population concentration and great economic dynamism. At the beginning, nine metropolitan areas ${ }^{1}$ were imposed, each one polarized by a large capital. These urbanized areas had strong growth in the 1960s and 1970s, however, this growth started to slowdown from the 1980s, due the agglomeration diseconomies, among other things.

Although the first metropolitan areas currently have decreased its growth rate, the conurbation phenomena have not ceased, reaching other cities, as the industrial and urban activities are dispersed throughout the country. Thus, by the 1988 Constitution, the states assumed the prerogative of the legal recognition of these metropolitan regions. Thus, what is observed in Brazil is that there has been a new metropolization, more formal than practice, causing a considerable increase in the number of metropolitan areas in the country, since in 1999 they totalized 17 and the total reached 23 in 2000, this number shall certainly be increased currently,

\footnotetext{
${ }^{1}$ The first nine metropolitan regions imposed in Brazil were: Grande São Paulo, Rio de Janeiro, Belo Horizonte, Recife, Salvador, Belém, Fortaleza, Curitiba and Porto Alegre.
} 
which surely, will focus on the worsening urban issue in the country (IBGE, Atlas Nacional do Brasil. Rio de Janeiro, 2000; Idem. Censo Demográfico, 2000).

\section{WHAT IS THE METROPOLITAN URBAN SPACE: BRIEF CONSIDERATIONS}

According to Corrêa (2001), a great capitalist city space is constituted by a set of different land uses juxtaposed with each other, where such uses define areas such as downtown, concentration locals of trade activities, services, management, different industrial and residential areas in terms of form and social content, entertainment and those reserved for future expansion of urban areas, among others. Thus, this set of different land uses shows in reality what is the spatial organization of the city, i.e. how it configures its urban space when fragmented, however, articulated once each part maintains spatial relations with each other, although with varying intensity and complexity, especially in metropolises.

However, in the process of understanding the metropolis transformation, it is necessary to consider two elements which differentiate it from other urban centers. The first refers to the metropolis size, which means state that some changes occurred due the demographic dimension of the metropolises, since the quantitative change implies in a qualitative leap. The second concerns the diverse singularities linked to metropolitan site, to urban and regional history, as well as the metropolises insertion process in the territorial division of labor at regional and international level, which means that such transformations verified in the metropolises are characterized by singularities representing the general, universal, typical of capitalist urban space processes are realized. About the metropolises, Souza (2000) is categorical in stating that

The Brazilian urbanization has on its metropolises the main focuses of its implementation. The millionaire size of these centers reveals an important facet of the Brazilian socio-spatial dynamic which is the economic and demographic concentration in just over a dozen national and regional epicenters. The concentration produced in the last decades generated, in the quantitative changes course, some qualitative changes, and among them, many problems [...] (Souza, p. 13, 2000).

An important fact to be considered in this metropolization process and its resulting problems refers to the demand for land and housing. These will depend on the direct relations of the new social classes, from migrants flow owner of an income level which qualify them to enter in the market of land and housing, as well as the possibilities of return on capital invested on both land and in estate real operations. However, regarding to the direction differential despite of the changes verifying in these lands, these will depend on the agrarian structure. This may enable operations or not related to land values besides questions as: different ecological conditions, the existence of transport routes and types of use which is intended for urban land. About the differentiated agrarian structures, Corrêa shows that

[...] in periphery distinct sectors may influence differently the transition from rural to urban. Thus, it is appropriate to emphasize that an agrarian structure based on speculative property tends to enable faster the transformation issued. The existence of wetlands in some periphery sector, on other hand, constitutes, as a rule, in an obstacle for land values (Corrêa, p. 17, 1995). 
Thus, the manner differentials that urban occupation, especially in periphery, will assume represents, regarding to residential use, an urbanization directed to high society segments, i.e. for those who have greater purchasing power and who can afford land endowed with great amenities, and a popular urbanization focus to attend the segments of lower income and may not afford land with great amenities, remaining the peripheral cities areas, with little or non-urban infrastructure. Therefore, the land owners' strategies will vary according to its property location, i.e. if it is located where other form of urbanization dominates.

However, in capitalist society there is non-interest in the capital different fractions involved in the construction of real estate, a wide varied, to build housing for the lower classes of society. This fact is explained basically for two reasons. The first is due the low wages of the lower classes, regarding to the housing cost which is produced capitalistically; the second occurs by interests convergence between the space agents producers, especially the land owners and real estate developers, with the building materials industry to produce only housings with innovations, use value that exceed the old houses to obtain an increasing price, fact which excludes the most popular sections of society in the process, confirming the socio-spatial segregation.

Regarding the production and reproduction of urban space by excluded social groups, we must consider that in such class society we verified large differences in the accessibility manner to goods and services produced socially. These differences are very striking, especially considering the capitalist production mode and its performance, mainly in peripheral countries like Brazil. Regarding to housing issue, its observed a selective property in which few can afford, then, a large part of civil society have non-access to their own home, mainly for not being able to pay for it, becoming one of the most significant symptoms of socio-spatial exclusion and associated with malnutrition, diseases, low level of education, unemployment or underemployment, among others aspects.

The housing possibilities for the excluded social groups in capitalist society become very difficult, remaining alternatives which exclude any right to full citizenship regarding to this issue. Thus, the slums have old mansions degraded and abandoned by the elite, which is now located in neighborhoods with more amenities, usually located far from those "undesirable", as well as the home built by the self-construction ${ }^{2}$ system in peripheral areas without amenities or adequate infrastructure, the housing complexes built via State and, as a rule, are located far from downtown and the slum ${ }^{3}$.

It must be considered that, from housing opportunities for social excluded groups, the slum provide the only housing type wherein these agents become effective space producers, since the other possibilities already mentioned here, require at least one type of linked relation to some agent type of space transformer. Such space represents a resistance mechanism and a survival strategy at the same time. Resistance and survival to all adversities imposed to social groups recently expelled from the field and/or from urban areas caused by structural unemployment, by

\footnotetext{
${ }^{2}$ The self- construction has been most common in large cities. In this housing possibility of excluded social groups, the residents finance the required material in small periphery stores, paying high interest rates, and use the weekends to build their houses.

${ }^{3}$ The Brazilian Institute of Geography and Statistics (Instituto Brasileiro de Geografia e Estatística - IBGE) considers slums as all agglomerates with at least fifty homes, poorly constructed, lacking of urban infrastructure and located on unbecoming land.
} 
urban renewal operations ${ }^{4}$, or even by natural issues, and who fight for right to the city, which in an immediate plan, corresponds to a dual problem solution; first the housing; second, the access to workplace (Corrêa, 2001).

Regarding to lands where usually the slums are located, these usually belongs to the government, which in recent years has sought to develop some urbanization programs in these areas aiming to offer a minimum infrastructure for its residents. This fact implies that the evolution, i.e. the slums progressive urbanization until become popular neighborhoods, will demand constant action of the inhabitants, which slowly and over a long period of time, will improve their homes and implement some economic activities, allowing some improvement in the services provision to the population. About the slum, Corrêa (2001) states that it constitutes

[...] the action results of social excluded groups who occupied land, public or private, sight of inadequate rule for land values and real estate development. These groups action, which occurs spontaneously, represents on one hand, a survival strategy, and on the other, a resistance to a social system which excludes considerable part of the population of their blessings ... It is an alternative way for producing space, which constitutes another environment with own characteristics that is distinguished from slums and settlements on the periphery. This is an environment of high population density. Is divided into rough shacks or improved, of masonry, located jointly each other. Separating shacks sets, there are winding, steep and fetid alleys (Corrêa, p. 163, 2001).

In this process, we must highlight the State action, which in turn implements some urban infrastructure arising from popular pressures exerted by its residents, sometimes organized into neighborhood associations, sometimes coopted for electoral reasons. According to IBGE, it is highlighted that in Brazil approximately $80 \%$ of the slums population are concentrated in metropolitan areas, and $70 \%$ of the houses are built by their own residents, usually a joint effort systems among friends and family as already mentioned (IBGE, 2000). Considering the growing problem of socio-spatial exclusion that the slum represents, being it associated with a dissolution of the sociopolitical and spatial structure in Brazilian large cities, although in different levels and connotations, the urban issue is raised as a real challenge because ii is constituted in a crisis, which represents the most visible and painful manifestation in the urban contemporary in the country.

In this sense, from this time, we centralize our efforts in aggravation and unfolding of the urban issue, highlighting the slums problem, also seeking to establish a relation between the national metropolis 'dysfunctional' size, its urban poverty, the organized crime which have in the slums territory their greatest activity, as well as the State and elites response to this issue. As mentioned before, some of these problems already existed, others, only latent, erupted scary and dramatic, mainly in cities from the $80 \mathrm{~s}$, as a result of an entire country historical context.

\footnotetext{
${ }^{4}$ About the urban operations, which usually occur in large urban centers of the country, we recommend reading the book Espaço-tempo na metrópole: a fragmentação da vida cotidiana, of Ana Fani Alessandri Carlos. In this book, the author well portrays the urban operation performed at Faria Lima Avenue, highlighting the socio-spatial consequences, especially for slum population who lives there.
} 


\section{SOME CURRENT ASPECTS OF BRAZILIAN DEVELOPMENT: THE FRAGMENTATION OF SPATIAL SOCIOPOLITICAL STRUCTURE IN OUR CITIES}

The increasing complexity of the country's urbanization, in close association with our economy complexity, which is typical of peripheral countries, reflects the changing patterns of industrial concentration and deconcentration. As we stated, it is right that the conflicts and urban problems worsen everywhere, especially in the two largest cities in the country. It is precisely in these two cities where decline the population growth rates more sharply, configuring a phenomenon that, in fact, is also experienced by most regional cities, though to a lesser level. About this fact, Souza (2004) states that

[...]This decrease in growth rates, therefore, is binding not only to long-term changes of the reproductive behavior (decline in fertility rates due to the massive entry of women into the labor market), which is not usually a problem or a bad indicator, but also to the attractiveness loss of national cities, in respect to the economic activity location and, for that reason, also regarding to migration flows.

It is important to emphasize that the metropolitan challenge since the 80 s consists not in containing the cities growth individually, as insisted some time ago, but to successfully address the social problems resulting from the way they established the urban issue in the country, especially in metropolises that, despite a demographic stagnation, is characterized by agglomeration diseconomies factors of all orders, i.e. using the expression of Milton Santos (1996), these cities suffer from a "metropolitan involution", which means they present a general deterioration framework of living conditions and habitability.

Anyway, the vicissitudes of these larger cities, the fragmentation of its spatial sociopolitical structure, should not be underestimated, since they contribute decisively to the "metropolitan involution", which the alluded socio-spatial fragmentation is its spatial expression more evident. In this context, it may be stated that a phenomenon occurred in these cities, denominated by Souza (2000; 2004) of 'negative retrofeed', inasmuch as the economic crisis and the agglomeration diseconomies factors accumulation undoubtedly contributed to the decrease, along the 1980s and 1990s, of the attractiveness of São Paulo, and dramatically, of Rio de Janeiro for migrants, causing a decrease in the migrate disposal due to short demand of employment and other reasons related to the deterioration of life quality in these metropolitan areas.

However, the metropolises continue to be the wealth concentration place per excellence, despite the industry relative decentralization and its internalization in the current Brazil. However, we shall observe, in the midst of those already mentioned characteristic and the escape of many skilled labors towards medium-sized cities in the country, it is evident that the urban issue in Brazil, mainly in the metropolises, denotes that it is also the poverty and misery concentration place, as well as socio-spatial tensions. In this sense, we agree with Rocha (1996), when he states that

"The urban poverty in Brazil is, above all, metropolitan, since this is an articulated poverty to the Brazilian economy dynamic center operation, mirror of the economy most dynamic sectors transformations and its negative impacts on the labor market. No wonder that one of the basic characteristics of this metropolitan poverty is the high rates of unemployment, besides the high percentage of female-headed households." 
Despite these characteristics, the urban issue in contemporary Brazil, not only impresses by its magnitude but mainly for its spatial socio-political unfolding, especially by slumization, as already mentioned, represents the most space and emblematic face of urban poverty in the metropolis. In recent decades, its territorialization by drug traffic ${ }^{5}$ has been the most characteristic feature. These, along with other socially segregated residential areas, as a rule, represent a very important point of logistic support for the gangs operating in toxic trafficking retail in Brazilian cities, especially in metropolitan areas where consumption is much higher.

However, it is not our purpose to label and/or stigmatize the slum space as a space where there is only violence related to drug trafficking. Firstly, It is true that the media emphasis the slums while areas related to retail drug trafficking, keeping in the shade, on the one hand, the good people living there, and on other hand, retailers not based on slums and other poor residential spaces: resellers users and traffickers working with retail distribution, operating from points of 'legal city' such as: restaurants, night clubs, educational institutions and middle class apartments.

The "disorder" sense that many experience, and reflects in popularized expressions by the media as 'big cities chaos' and 'civil war climate' in slum areas, is partly caused by the negative social impacts of the economic "order" evolution on the employment level, through a technological modernization, based on a saver technical progress of labor. However, it is undeniable that the slums are, for diverse reasons, but mainly because its spatial organization, the preferred stage of trafficking territorial phenomenon of urban space parts by traffickers. Souza (1996) statement is salutary on this issue when clarifies that

The slums arise for criminals as ideal supporting points and refuges: there, they count not only with the protection provided by the own space - a labyrinthine spatial structure with narrow and high density occupation streets - but also with real human shield who is, for the traffickers, the slum population.

However, regarding the population living in slums, one point shall be clarified because the mistaken and distorted interpretation has only contributed to feed the preconception against slum residents by the middle class, which sometimes has adopted an uncritical attitude, not to say unfair. Whether often, but not always, the slum population is friendly to traffickers or at least more sympathetic to them than to police, there is a reason. First of all, whether the local traffickers is identified as "bad boys" and distinguished from workers, are at the same time, faced almost as equal to the slum residents.

This fact explains why they have the same social origin, share the same spaces and, to some extent, the same values; but the police represent an external power to the slum, most brutal and discriminatory to poor common people, besides also commonly corrupt. Rarely constitutes the repressive State arm, since their incursions on slums, also a segregated space, there is only to suppress and humiliate its residents. Another point in this regard refers to cooptador effect of "gifts" that traffickers give to slum residents.

In this case, in front of the complete lack of assistance from the State, have a huge psychological effect to its residents; a sports court, parties, among others, "replace", if this is the

\footnotetext{
${ }^{5}$ The drug trafficking issue is very old in the slums of Rio de Janeiro city, then, does not constitute a phenomenon of the 1980s The new fact is that over this decade the binomial "marijuana +.38 gun " was gradually giving space to the combination "cocaine + AR-15 rifle", indicating a level change in the traffickers power and organization.
} 
correct word, actions that shall be performed by the governments. Finally, we must not forget that, at a time when unemployment is high, as well as the underemployment and the consumer desire among the young from the slums, the fact that the drugs business provides greater possibilities of earnings than those provided for a minimum salary job, exerts great attraction, despite all the risks of a criminal life.

The slums territorialization process increasing by trafficking and drugs has led to a sociopolitical spatial structure fragmentation in national metropolises, especially in larger. In respect to non-slum areas, ordinary neighborhoods, "the neutral areas", according to Souza (2004), represent non-security areas at all, therefore, dangerous spaces, since there is a lack of protection by any organized crime faction against the possible crimes that may be committed in these areas, unless those offered by the State in this sense", as guarantor agent of "public order", however, is greatly reduced, in practice, when challenged by enclaves controlled by drug traffickers and prove unable to ensure security in the "neutral areas" (Souza, p.65, 2004).

\subsection{As respostas do Estado e das elites à questão urbana}

The State responses to urban issues, as well as much of the Brazilian elites, have been of an 'escapism' ${ }^{\prime}$, which somehow, has only aggravated this situation. Often, much of the public opinion sees in the Armed Forces the only moral and militarized institutions in position to combat the organized crime, opposite to the total failure of the police apparatus. This issue appears as true symbol and incarnation of a less corrupt power and more capable to provide protection than civil power to many Brazilians especially the middle class and part of the working class.

In this sense, the most commonly response practiced by the Brazilian government, at diverse levels, is the constant repression increase to the criminality, the street vendors, the urban strikes, in short, all of those elements considered 'dysfunctional' by the formal system, according to Santos (1994). Thus, the social question continues to be treated as a police matter in the country, when it is known that its roots are in the lack of prophylactic actions, of wide and long range which, in turn, will gradually eliminate all the problems faced today in the big cities of the country. The system is compelled to respond to the violence originated from the violence which is the social injustice with police violence.

The expansion and consolidation of the drug trafficking power in Brazilian slums, especially in the large cities of the country, is the best example related to its contemporary urban. In this perspective, this 'parallel order' which has been installed due to its unpopular content of the modernizing order binomial, associated with all consequences left and brought to the current framework of state order, added also to the police violence intensification against poor people, especially slum residents, constitutes a strong contribution to the socio-spatial segregation in Brazilian cities currently, as also increases the non-legitimation of the state and its institutions in the eyes of those less fortunate in society.

Regarding to civil society responses to the urban issue, especially the middle class with greater purchasing power, the society militarization, then, the urban militarization, in regard to private security hiring, firearms purchase by civilians, as well as the armed forces participation to

\footnotetext{
${ }^{6}$ Term used by Marcelo José Lopes de Souza when he analyzed urban issues from the 80's to nowadays. On this issue, you must see the same author in 1996, 2000, 2004.
} 
confront the crime, and notably the spatial segregation, has been the response and/or "outputs" most often utilized by this society layer. About the segregation issue, Corrêa (2001) states that

The segregation process relates especially to residential issue, relating to, much more, therefore, to labor force reproduction. Segregation is a process which originates the trend to a spatial organization in areas of "strong internal social homogeneity and strong social disparity between them". (Corrêa, p. 131, 2001)

The ordinary citizen insecurity feeling in Brazilian large cities has increased considerably. In this case, of the point of view of those who hold great purchasing power and feel very threatened by the violence and who experience it in their day by day, the auto segregation deployed in gated communities seems to be the solution to such situation, becoming a real "Eldorado" for the upper middle class derived, in part, from old prime areas of the city, which lies at the other social extreme to slum, which is characterized by

[...] auto segregation, i.e. social group isolation, which providing income, may reside where they please. And the new residence choice is influenced by the massive advertising surrounding the amenities and new life style. The auto segregation translates into the wall and gatehouse controlling who enter and leave; in the private security which constantly runs through the pleasant internal roads of the condominium. And also the exclusive use possibility of certain personal services, restaurants, diverse and abundant entertainment and even an efficient public education. (Corrêa, p. 165, 2001)

In this same perspective and about gated communities, Souza (1996) defines as

[...] the ultimate symbol of what may be designate as auto segregation, which represent the counterpoint of the induced segregation (which basically refers to irregular settlements in the city suburbs and slums); in this case, the segregation is induced by the poverty, by the lower income, which forces a portion of the population to be subjected to live in spaces almost devoid of infrastructure, neglected by the state and even unhealthy ... The gated communities incorporate all a range of safety devices: walls and gatehouse with security guards at the condominium entrance, gatekeepers controlling the visitors entry in each individual building, intercom to gatekeepers communicate with residents of each apartment. (Souza, p. 54-57, 1996)

However, according to the author, the "solution brought by condominiums", therefore, auto segregation, is doubly illusory, constituting in fact a "escapism" in the author's words, for just that portion of society who may pay for a more expensive space and an area equipped with best amenities, meaning in fact an attempt to solve their specific problems and, non-often, the social and more general problems which generate the issues subsidizing the auto segregation which does not always prove as effective by non-prevent kidnappings or other problem related to the urban issue in Brazilian cities.

However, the elites "escapism" are not restricted to gated communities. Another auto segregation form refers to shopping centers, which, from 80 s were incorporated to urban landscape of our cities, as well as other large cities of the country, composing, parallel to these condominiums, the typical framework of escapism. According to Souza, "... Although shopping is less exclusionary than the condominiums, it is more exclusionary than the traditional sub-centers, 
more "open" and "permeable" (Souza, p. 67, 2004). About the shopping, Nascimento (2003) reveals that

[...] is a miniature city; born planned by the entrepreneur, who cares on its location at a certain point, of its rational organization and regulated operating which are arranged in domestic market and previously accepted by all unit holders who operate within the set. Each planning phase deserve special analysis, under the circumstances which promote ordering and qualify them, becoming thus socio-spatial segregation elements. (Nascimento, p. 29, 2003)

Outside the exclusive condominium and shopping centers are the other city areas, becoming almost exclusively by other functions, as a whole, which comprise the cities fragmentation and articulation movement, producing a daily modern world, linking up a wide consumption dissemination which, in turn, creates and recreates the commodity kingdom, in the consequent capitalist relations penetration in domestic sphere associated with the capital reproduction requirement through the social relations reproduction which produces a lifestyle, a way of consumption, a type of consumer, values and needs, and may not stop because represents the society movement.

\section{FINAL CONSIDERATIONS}

This study aimed to show some contemporary aspects of Brazilian urbanization, especially in its cities. Therefore, we tried to draft a historicity to highlight the problem of urban issues, notably, the spatial socio-political structure fragmentation, which among other aspects indicates a current extreme gravity situation. This fragmentation with the urban "ungovernability", in fact, seems to be a synthetic spatial expression of many of the main obstacles towards building the metropolitan environments more worthy to live.

In this sense, the cities spatial socio-political structure fragmentation constitutes a brutal specialized picture in which is the current social issue of these large cities of the country, as well as the negative transformation of what is meant by city and what is desired for it, while reproduction locus of social relations as a whole. In fact, all aspects mentioned here are mutually related, therefore, any of them shall be enough to explain this fragmented situation emergence which is set before our eyes in the contemporaneity, therefore is unproductive try to establish now or at any time, parameters to understand the urban issues in Brazil.

Other phenomena are evidenced in national cities, or from them, somewhat related to this fragmentation, as well as the housing deterioration and the social climate such as socio-spatial segregation, increased suburbanization among others. We do not wish to pass a simplistic image of the urban issue in the country, therefore, it is highlighted that the metropolis character, as an extremes space, is accentuated in the spatial socio-political structure fragmentation mat, while being the wealth concentration place, power centralized and manageability.

Despite this, it seems we are watching a demetropolitanization process, considering a further urban population disaggregation according to the agglomerates sizing, defined as the sharing with other major centers of new urban population contingents, i.e. we are alluding to a demetropolitanization existing in parallel with the metropolis phenomenon keeping the same problems related to urban issues in the country. On a national scale, the democratic-representative 
regime, characterized by corruption, inefficiency, consumerism and elite indifference, is shown incapable to mitigate substantially the population socio-spatial problems.

A fair urban space and guarantor of a good life quality depends on a fair society, but the reverse is also true. Overcome the problems associated with urban issues inferred not only eliminate the social relations that generated it, but also overcome the spatiality which induces the reproduction of these relations at all scales, especially the local. These transformations require, in fact, a confrontation of the capitalist civilization model without which a more equitable social development in these large cities shall not be aimed.

\section{BIBLIOGRAPHY}

1. BALTAR, Paulo Eduardo de Andrade; DEDECCA, Cláudio e HENRIQUE, Wilnês. Mercado de trabalho e exclusão social no Brasil. In: OLIVEIRA, Carlos Alonso Barbosa de e Matoso, Jorge Eduardo Levi. (orgs.). Crise e trabalho no Brasil. Modernidade ou volta ao passado? São Paulo: Scritta, 2. ed. 1997.

2. CORRÊA, Roberto Lobato. Trajetórias geográficas; Prefácio Milton Santos. 2. ed. Rio de

3. Janeiro: Bertand Brasil, 2001.

4. O espaço Urbano.São Paulo: Ática, 1995.

5. GOULART REIS FILHO, Nestor. Evolução urbana no Brasil. Pioneira, São Paulo, 1968.

6. NASCIMENTO, Gerson Gomes do. Shopping-Centers: elementos de (re) produção urbana na Zona Sul de Natal-RN. Dissertação (Mestrado) - PPGE/UFRN, Natal, 2003.

7. IBGE. Censo Demográfico, 2000.

8. ROCHA, Sônia. Pobreza e desigualdades regionais: caracterização recente e perspectivas. In: IPEA. A economia brasileira em perspectiva. 1996, vol. 2. Rio de Janeiro: IPEA, 1996.

9. SANTOS, Milton. A urbanização Brasileira. 2. Ed. São Paulo: Hucitec, 1996.

10. SOUZA. Marcelo Lopes de. Brasil Urbano. (Orgs.) Edézio Fernandes; Márcio Moraes Valença. IN: Alguns aspectos da dinâmica recente da urbanização brasileira. Rio de Janeiro: Mauá, 2004.

11. O desafio metropolitano: um estudo sobre a problemática sócio-espacial nas metrópoles brasileiras. Rio de Janeiro: Bertrand Brasil, 2000.

12. . Urbanização e desenvolvimento no Brasil atual. Ática. São Paulo: 1996.

13. VILLELA, Aníbal Vilanova e Wilson Suzigan. Política de governo e crescimento de economia brasileira, 1889-1945. IPEA-INPES, Instituto de Planejamento Econômico e social, Série Monográfica 10, Rio de Janeiro, 1973. 